\title{
Citizen participation and discontent in three Southern European health systems
}

\author{
Mauro Serapioni*, Ana Raquel Matos \\ Centre for Social Sciences, University of Coimbra, Colégio de São Jerónimo, Ap. 3087, 3001-401 Coimbra, Portugal
}

\section{A R T I C L E I N F O}

\section{Article history:}

Available online 6 June 2014

\section{Keywords:}

Citizen participation

Southern European health systems

Health reforms

Crisis and health

Italy

Portugal

Spain

\begin{abstract}
A B S T R A C T
Participation has featured in political agendas in recent decades and the domain of healthcare has not been indifferent to its appeal. Although emerging later than in other European regions, the involvement of civil society in healthcare decision-making procedures has proved one of the biggest challenges facing Southern European health systems. The health systems of the countries considered in this analysis Italy, Portugal and Spain - underwent reforms that brought citizen participation to the forefront of the health system. Through national laws or health plans, each of these countries has recognised the need to promote participation in order to 'give a voice' to citizens in the health sector. Accordingly, a range of significant activities have been implemented in the region, although they have been developed unequally within national territories, at different paces and involving the mobilisation of different actors. This article focuses on the most relevant experiences of citizen participation designed and implemented in the three selected countries, describing their key features and potential, as well as the main critical issues and contradictions that have emerged over time. Particular emphasis is given to the impact of the current financial crisis on Southern European national health systems, especially in terms of participatory methods, the way in which citizen participation is progressing and civil society's reaction to these important changes.
\end{abstract}

(C) 2014 Elsevier Ltd. All rights reserved.

\section{Introduction}

The concept of participation has had a major impact on political rhetoric and agendas and has been promoted as the necessary element required for a more just form of democracy. The discourse of citizen participation has become a priority and its applicability has been widely proclaimed touted, even though this has usually involved very little contact with real practices. In recent decades, following the call for more citizen participation, Southern European health systems have accepted the rhetoric of participation as good governance practice. In fact, as often recommended by the World Health Organization (WHO), citizen engagement in healthcare decision-making processes has become a structural principle of National Health Systems (NHS) in countries such as Portugal, Spain and Italy, which have enshrined their ambitions to implement participatory mechanisms in laws and national health plans. In this context, it is important to mention the launch of the Healthy Cities project by the WHO Regional Office for Europe, with the aim of

\footnotetext{
* Corresponding author.

E-mail addresses: mauroserapioni@ces.uc.pt, mauro_serapioni@libero.it (M. Serapioni), amatos@ces.uc.pt (A.R. Matos).
}

incorporating the principles of Health for All, established in 1978 in the Declaration of Alma Ata, and the Health Promotion guidelines emerged from the Ottawa Charter. Both projects emphasise the empowerment of individuals and communities to enable them to exert more control over factors which have an impact on their health and well-being. Healthy Cities networks have been established in more than 30 European countries, including those analysed in this article (WHO Regional Office for Europe, 2002).

The main focus of this article is civil society's engagement with health systems. It begins by summarising the specific features of the Italian, Portuguese and Spanish health systems and the main stages in their reform processes, with a particular focus on the impacts of the current financial crisis on the NHS and the reactions of civil society. The most relevant initiatives of citizen participation are presented, highlighting their key characteristics and potential, as well as the main critical issues raised.

\section{Civil society's involvement in healthcare systems: potential and constraints}

Since the 1980s, participation has become "the mainstream development practice" (Pateman, 2012: 7). Nowadays, certain 
participatory mechanisms are emphasised as a means of reinforcing social inclusion, with the aim of enhancing or restoring a sense of belonging to the community, as well as serving as a source of emancipation, allowing for direct control of decision-making and greater control over the political system (Roberts, 2008; Pateman, 2012). A new social actor, defined as the participatory citizen, has emerged from this participatory governance (Newman, 2005), endowed with a new set of combined rights/duties, namely to present opinions, to propose, control, assess, judge and decide.

In recent decades, there has been a growing interest in deliberative methods as an innovative strategy for strengthening interaction between policy makers and citizens, promoting stronger democracy and contributing towards quality decisions. Participation through deliberative practices has taken many forms in the various spheres of social life, shaped by two theoretical strands of democratic theory: "deliberative democracy" and "participatory democracy". The deliberative approach, developed since 1980, is based on communication as a process that allows citizens to participate in the construction of the common good (Habermas, 1996; Cohen, 1997; Gutmann and Thompson, 2004; Dryzek, 2009). The latter is the so called "participatory" approach, whose origins date back to the intensification of globalization processes which led to a reformulation of several aspects of nation states, including decision-making processes (Santos, 2002). Unlike deliberative democracy, the participatory democracy approach is based on a project firmly anchored in the formulation of public policies that effectively tackle inequality through new participatory practices. It is founded on the idea that citizens have the specific knowledge and capacities to engage and intervene in policymaking processes and influence technical decisions, and considers participation a universal right that must be freely exercised (Santos, 1998; Pateman, 2012).

Although their concept of participation differs, both approaches have emerged to uphold the argument that new practices involving citizen engagement should complement representative democracy (Santos, 2002; Delli Carpini, 2004).

Participation has become a corollary to many areas of social life and healthcare has been no exception. The recognised virtues of participation in healthcare systems highlighted by literature on the subject include the following: a) the capacity to strengthen the voice of health service users as a strategy for overcoming the democratic deficit that characterizes heath systems after the managerial reforms of the 1990s (Cooper et al., 1995); b) users' experiences and their knowledge, as a means of improving the quality of healthcare decisions (Charles and DeMaio, 1993; Bovemkamp et al., 2009; Lehoux et al., 2009); c) citizen participation as a means of increasing the legitimacy and accountability of healthcare systems (Tritter and McCallum, 2006); d) the fact that citizen participation brings community needs and health service responses closer together (Franskish et al., 2002); e) the fact that the public healthcare system is more effective when decisions reflect the users perspective (Scuthfield et al., 2006; Matos, 2011).

Despite the very good intentions and praiseworthy efforts pursued in several areas around the world, experiences of participation in health systems are, as yet, unlikely to be fully implemented (Zakus and Lysack, 1998; Serapioni and Matos, 2013). It is important to stress that participatory activities applied to the sphere of healthcare, such as citizens' juries, deliberative voting processes, focus groups, etc. also reveal constraints, specifically in terms of representativeness, since participation schemes fail to take into account the social diversity of communities, especially excluded groups, (Frankish et al., 2002; Tritter and McCallum, 2006); the potential for influence and the power imbalance between the sponsors of the deliberative process and the participants (Serapioni and Duxbury, 2012) and the lack of any assessment focussing on the effectiveness of participation in healthcare issues (Rowe and Frewer, 2004; Lehoux et al., 2009). There is also a serious risk of idealising such practices, likening them to magic formulas for solving the problems of the health system (Zakus and Lysack, 1998; Rifkin, 2009) and a resistance on the part of healthcare professionals and managers to implementing the outcomes of public participation in healthcare deliberative processes (Martin, 2008). With regard to the latter point, citizen involvement is more widely used as a "technology of legitimation" (Harrison and Mort, 1998). In these situations, the low level of institutionalisation of such mechanisms within the healthcare system (Abelson et al., 2003) easily turns them into forms of participation that are occasionally activated on the initiative of the health authorities at excessive financial and human cost, considering the outcomes they produce.

These limitations are even more intense and visible in the Southern European countries affected by institutional fragmentation, a lack of financial resources, and a short history of citizen participation. In Southern Europe, the trend towards involving patients, users, caregivers and the general public in policy-making is a relatively new phenomenon. National health plans implemented in the previous decade acknowledged the lack of formal mechanisms for participation in healthcare systems and highlighted the importance of placing people at the core of policy decision-making. Various initiatives were therefore launched to encourage citizen participation in healthcare systems.

Nonetheless, the existence of alternative approaches to participation in healthcare systems which extend beyond technocratic and academic formulas cannot be ignored, particularly in times of economic crisis. In this context, protests and other forms of collective action appear to introduce the somewhat neglected concept of civil society into the debate, reflected in the mobilisation of the lower classes in the fight to participate and have a voice in healthcare decisions (Matos, 2011). Although this is a more comprehensive and utopian approach to participation (Neveu, 2011) it can no longer be dismissed when citizen participation is at stake.

\section{Common features of the three Southern European health systems}

In his study of the different worlds of welfare capitalism, EspingAndersen (1990) identified three "welfare state regimes": the social-democratic system in Scandinavian countries, the conservative system in continental Europe, and the liberal system in Anglo-Saxon countries. Esping-Andersen's approach has been criticised for not giving enough importance to Southern European countries, which were considered a subcategory of continental Europe. Other scholars (Ferrera, 1996; Rhodes, 1998, 2000; Karamessini, 2007) have defended a new approach to identifying other specific features of the Southern Europe social system, without denying the effectiveness of the welfare model developed by Esping-Andersen. During the period of Keynesian capitalistic expansion (1945-1975), one of the principal features of this social Europe was the introduction of a dualist system of social protection with generous allowances for the main market categories and limited protection patterns for marginal categories. Another distinctive feature of the welfare state in Southern Europe concerns health systems characterised by a universal approach (Ferrera, 1996).

Other authors have worked on analysing and identifying the specific features of the health systems in Southern European countries. A pioneering study by Figueras et al. (1994) identified common characteristics in the Italian, Spanish and Greek health systems, such as a specific healthcare system model, the common historical evolution of the national health services, similar models 
for the organisation and provision of services, a limited range of objectives, a shared crisis and similar responses to this crisis. Guillén (2002) studied the main political, economic and social factors that facilitated the establishment of national health services in 1978 in Italy, 1979 in Portugal, 1983 in Greece and 1986 in Spain.

In addition to socio-political factors, the following common features of the health systems in the Southern European region should be noted: i) the gap between universal NHS promises and the difficulties encountered in their implementation, above all in relation to methods of financing health expenditure (Giarelli, 2006); ii) inefficiency and low levels of management competence (Cabiedes and Guillén, 2001); iii) the important role developed by non-professional resources, such as families, kinship, neighbourhoods, and voluntary associations in the healthcare systems, (Viegas, 2004; Jovell, 2008; Giarelli et al., 2012); iv) the inadequate level of user rights guaranteed by the respective healthcare systems (The Health Consumer Powerhouse, 2009).

\subsection{Reform processes in the health systems of Italy, Portugal and Spain}

This section outlines the evolution of the health systems in Italy, Portugal and Spain, identifying the main phases in the reform processes and the key actors, results, and new priorities established.

\subsubsection{The reform of the Italian health system}

Law No. 833 of 1978 created the Italian NHS, replacing a health system that had been divided into more than 100 public and private health insurance schemes. This reform introduced universal access to healthcare and a decentralisation process on a regional and local level. However, signs of inefficiency soon emerged, as well as conflicts between the different levels of authority. The public finance deficit in the regions gradually increased and the central government has had to intervene systematically to cover it (Lo Scalzo et al., 2009). The growing dissatisfaction of many sectors of society and the constant increases in spending on healthcare during the 1980s led the government to reform Law 833/1978. This second reform (Legislative Decree No. 502/1992) introduced some internal market elements inspired by the British model and initiated a process of decentralisation by transferring responsibilities to the regions. Increasing financial and managerial problems and the progress of the decentralisation process led the government to launch a third health reform (Legislative Decree No. 229/1999), aimed at strengthening the involvement of the municipal communities in health planning activities and integrating the health and social services in order to provide better services, particularly to disadvantaged people (Lo Scalzo et al., 2009). However, due to a change in government, this reform was only partially implemented. Another decisive step in the reform process was the modification of Section V of the Constitution (Law No. 3/2001), which redefined the relationship between the various spheres of government, conferring on the regions the right to legislate, plan and manage health services (Dirindin and Pagano, 2001).

In the years which followed, the conflict between the state and the regions continued. The regions have demanded more autonomy but have also faced difficulties in reducing expenditure on healthcare. Meanwhile, the Italian state has been unwilling to give up its coordination and leading role, in order to avoid the regions adopting different models for their healthcare systems (Maino, 2009). Currently, the National Health Service is dealing with traditional problems - related to quality and efficiency - in addition to the threat of an increase in the existing disparities.

\subsubsection{The reform of the Portuguese health system}

After the 1974 Portuguese Revolution the restructuring of the health services began, culminating in the creation of the Serviço Nacional de Saúde (NHS) under Law 56/1979. The NHS brought about the unification of the health system, a decentralised and shared management and a supplementary role for the private sector. However, since its inception the NHS has had to face a number of problems, such as under-financing, the concentration of resources in the hospital sector, poor integration between primary and secondary care, and unequal access to the public service due to the existence of a strong private sector (Bentes et al., 2004). A number of legislative interventions have been introduced in the last twenty years to remedy this situation. One important stage in the reform process was based on the 1990 Basic Health Law and the National Health Service Statute, incorporating certain elements of neoliberal political thinking in vogue at the time in western countries. The major role attributed to the private sector in the supply of care and finance led to discrimination in terms of access to health services and brought the problem of equality to the fore of the debate once again. This period, from 1997 to 2002, was characterised by the adoption of New Public Management principles. Third-party agencies were contracted and a split was therefore created between the financer and the service provider.

In 2004, the new National Health Plan 2004-2010 (Portugal, 2004) was approved and various initiatives were implemented: a) a new legal statute for public hospitals and the reorganisation of hospital services; b) the creation of the first Family Health Units in 2006 and the establishment of Primary Health Care Groups across the country in 2008; c) the Integrated Continuous Care network, set up in 2006 to respond to the needs of the chronically sick and dependent.

The main issue in the Portuguese health reforms appears to be their limited implementation, which depends on multiple factors, including the lack of continuity in health policies, bureaucratic complexity, a lack of citizen participation, etc. In addition, the Portuguese healthcare system is nowadays composed of three subsystems: an NHS, a public insurance sector for public sector workers, and a private sector (Barros and Simões, 2007). This segmentation may lead to increased inequalities in healthcare, particularly in the current economic context.

\subsubsection{The reform of the Spanish health system}

In 1977, after the restoration of democracy, the Spanish Ministry of Health and Social Security was created. In 1979, the Autonomous Communities (Comunidades Autónomas - CA) began to take charge of public health, although the management of health services remained the responsibility of the National Institute of Health. In 1986, following approval of the Ley General de Sanidad, the Sistema Nacional de Salud (NHS) was established. It recognised the right to health for all citizens and foreign residents in Spain and accelerated the decentralisation process involving the $17 \mathrm{CA}$. From this point onwards, significant reforms were promoted. The management and organisation of health services was the main objective of the 1990s reforms. Different privatisation strategies were developed (Sánchez Bayle, 2003), but some relevant issues remained unresolved, namely how to improve access to healthcare and the quality of services, how to involve users and professionals in decision-making processes and how to accelerate the regional decentralisation process.

In order to meet new challenges and strengthen national cohesion after the decentralisation of the health administration had been completed, Parliament passed Law No. 16 of 2003 (Cohesión y Calidad del Sistema Nacional de Salud), with the aim of developing coordination and cooperative measures among the different public health institutions to guarantee health rights to 
citizens and ensure equity, quality of healthcare and participation. In 2004 the socialist government began introducing a number of policies to address the new challenges and priorities: a) the development of preventive and health promotion programmes; b) containment of the price of pharmaceuticals and other health resources; c) encouraging cooperation among the CAs to improve access to healthcare and equity. However, since 2007, the financial crisis led to the fall of the socialist government and consequently to substantial cuts in health spending, as well as the launch of the privatisation process and, in more general terms, the restructuring of the health system. In April 2012, a new law was introduced which made health cover employment-based rather than universal (Garcia Rada, 2012).

\subsection{The financial crisis: implications for health systems and the reaction of civil society}

The financial crisis which, as noted in the previous sections, has been negatively affecting the consolidation of citizen participation, and has created an unfavourable economic environment for investment in the three chosen countries, including investments in healthcare. In terms of the public's reactions to the state withdrawal from supporting participation in healthcare, as well as the increasing number of recent publications on this specific topic, it is important to highlight these aspects.

In recent decade, given their socio-economic development, Southern European countries have improved the living conditions of their populations as well as the provision of healthcare. Despite the limitations and difficulties facing the national NHSs, life expectancy and certain other health indicators put those countries at the top of international health rankings. Nevertheless, inequalities still pervade Southern European health systems. In this already complex situation, the impact of the current financial crisis, coupled with strong austerity measures, is being identified as the main factor responsible for reducing access to, and use of, preventive health services.

The financial bailout signed by the Portuguese Government, the European Commission, the European Central Bank and the International Monetary Fund, for example, required cutting down on spending in all sectors, dramatically affecting the health sector. In such situations, the shrinking budgets allocated to public health systems began to accentuate the already existing inequalities, having an even greater effect on access and compromising the quality of healthcare (Augusto, 2012). In addition, the crisis has also led to increasing unemployment, poverty, insecurity and stress among populations, leading to higher rates of mental illness and suicide (Faria, 2011; Karanikolos et al., 2013). Patient and citizen perceptions of the quality of the healthcare system are therefore worsening (Belvis et al., 2012), leading civil society to classify austerity measures and their effects as a setback to acquired social rights and an outrage (Faria, 2011; Graça and Loureiro, 2012; Karanikolos et al., 2013).

Currently, the public health sector faces a very tough fight, given the context of the financial crisis within which Southern European health systems are trying to ensure their sustainability. Several considerations have emerged regarding how to maintain the NHS, such as creating mechanisms for future control of health expenditure and the public sector (Barros, 2012), introducing best practices for information on healthcare systems (Fernandes, 2011), valuing and encouraging citizen participation in policies and health services (Graça and Loureiro, 2012), and encouraging collective non-compliance initiatives (Faria, 2011).

Collective mobilizations against austerity have emerged as participatory channels, challenging closed decision-making processes and attempting to influence them. The various protest events held in countries such as Portugal, Spain and Italy in recent years, together with their demands and proposed solutions for healthcare are illustrative of the need for the greater and more effective involvement of civil society in solving these problems (Karanikolos et al., 2013).

In Portugal, for example, the crisis is forcing health units to close and is leading to a hasty reform of the National Health Service (Augusto, 2012), which has, in turn, led to further protest actions. Additional measures, including the increasing of user fees and reducing State subsidies for medicines, have also led to expressions of strong public disapproval. In terms of the health protests registered in the previous decade, it may be said that the crisis has highlighted previously unknown aspects of participation. One such example is the involvement of doctors in unprecedented protest actions which, in 2012, extended beyond their right to strike when they took the streets to protest in defence of the Portuguese NHS.

In Spain austerity has also brought a strong health protest movement to the fore known as "marea blanca" (the white tide), in opposition to the cuts and privatisations of the public healthcare system. In June 2013, the Assembly of Health Workers and Users Platform ("Patusalud") - the organiser of a strong protest rally all over Spain - recalled the massive support given by Madrid society to public health, as expressed in the consultation process organised in May. On this occasion, 99\% of the approximately one million people who voted gave an affirmative answer to the question: "Are you in favour of universal quality public health management and against privatization and the laws which allow this to take place?"

Italy has also faced strong protest actions due to austerity measures, and their causes seem to be very similar: an increase in out-patient charges, a reduction in the quality of services and greater social and regional inequality.

\section{Citizen participation experiences in Southern European health systems}

\subsection{Italy}

The discourse on citizen participation has characterised the entire reform process of the Italian health system. In the 1978 reform of the health system, citizen participation was considered a guiding principle and a strategic issue (Ardigò, 1997). However, the reform did not produce institutional mechanisms that were capable of ensuring the effective involvement of users in healthcare facilities (Ardigò, 1997; Altieri, 2009). After a long absence from the political debate on the health system, the issue of participation was reintroduced by Law 502/1992, which established a system of quality assurance to be evaluated by users and their spokespersons rather than by technicians and health professionals alone. In addition to individual participation through observation, proposals and campaigns, Article 14 of Law 502/1992 also encouraged collective participation, such as the presence of user and voluntary associations in hospitals and health centre, both to take care of patients and to act as advisory and advocacy organisations.

About 20 years after the introduction of Law 502/1992, innovative participatory experiences are still rare in the Italian regional healthcare systems. One of the most interesting examples is the Emilia-Romagna region which, under Regional Law 19/1994, established that health centres and hospitals should provide patient and user associations with suitable facilities for their representational and advocacy activities. In addition, the law provided for the establishment of Comitati Consultivi Misti (Mixed Advisory Committees - MAC) which hold monthly meetings and are composed of patients' representatives and user associations, together with a minority component that includes health service administrators, general practitioners and other health 
professionals. Although consultative, they have developed an interesting pioneering deliberative approach by involving all actors in the field of healthcare, offering citizens' representatives the chance to contribute to the debate on health services and on their own critical issues. Despite this potential, certain critical aspects have also been highlighted: i) a decrease in levels of participation in MAC activities by patient associations; ii) the dissatisfaction of its representatives regarding their lack of influence on decisionmaking; iii) the difficulties faced by MACs in representing all citizens, although they are recognised as dealing with issues which are of concern to all users (Altieri, 2009; Serapioni and Duxbury, 2012).

Another interesting citizen participation initiative concerns the Plans for Health (PFH) developed in the Emilia Romagna region. This refers to three-year plans developed by Local Health Units to foster a strategy for health promotion. The main stages of the PFH process are: 1 ) assessing health needs; 2 ) selecting priorities, 3) designing projects; 4) implementing measures; 5) monitoring and evaluating the results. The first two stages of the process - needs assessment and priority setting - require the participation of different social groups in the district: citizens (individuals or collectively represented), associations, volunteers, unions, etc. In the participatory activities carried out between 2000 and 2004, more than 2000 citizens involved proved to be highly motivated and ready to acquire the competences needed to actively participate in PFH. For this reason they were renamed "competent citizens" (Biocca, 2006). Among the most critical issues highlighted in this experience, the following should be noted: i) efforts are limited to listening to citizens' voices, rather than promoting their effective participation in decision-making (Nicoli et al., 2006); ii) the ability of PHF to engage all type of users rather than just those already belonging to associations has been questioned (Palazzi et al., 2002); iii) there is a greater focus on the participation of institutional actors and less effort to engage non-organised social actors (Altieri, 2009).

Another participatory initiative has recently been promoted by the Tuscany region within the Società della Salute (Society of Health). Here, Regional Law 40/2005 has created three citizen engagement mechanisms: the Participation committees, consisting of representatives of the local community and advocacy associations; the Third sector consultants composed of voluntary organisations and third sector representatives operating in the social and healthcare systems; the Agoras, which encourage the involvement of all citizens in the Society of Health catchment area and meet at least twice a year.

However, the Participation committees and Third sector consultants were not regulated by regional law, either in terms of the participatory method and decision-making process, or with regard to the available resources for their organisation and operation. Thus, by the end of the experimental phase, both the inadequate definition of the structural and processing aspects and insufficient investment in training and developing the participants' competences in this particular case contributed towards weakening the citizen engagement strategy deployed by the Tuscany region (Cervia, 2011).

Other specific cases of citizen involvement in the health system may be cited, such as the "participatory construction of the Citizen's Charter" in the Province of Trento health services in 2001 and 2002 (Corposanto and Passerini, 2002), and the "Humanization Management System" project developed in 2005 and 2006 by the Veneto region (Lo Scalzo et al., 2009). In both cases citizens were involved via voluntary associations already operating in the health sector.

\subsection{Portugal}

In Portugal, Law No. 56 of 1979 granted users and professionals the right to participate in the planning and management of services, both at central level (through the National Health Council) and on a regional and local level (by participating in regional health councils and municipal health commissions). However, this recognition of the right to be involved was not followed by executive decrees establishing the available resources, organisational models and methods required to put concrete participatory activities into practice.

Subsequently, both the 1990 Basic Law on Health and the 1993 Statutes of the National Health Service recommended the implementation of citizen participation mechanisms. However, citizen participation was only recognised as an essential strategy for improving the performance of the Portuguese health system in the 2004-2010 National Health Plan. The National Health Plan acknowledged that although legislation from the 1980s onwards had guaranteed some formal processes to encourage participation in the healthcare system, they had not been implemented in practice. It therefore recognised the need to promote "community and social empowerment through the authorized representation of a community or a group with an interest in that community" (Portugal, 2004: 66).

Portugal is singled out for its lack of initiative in experimenting with participatory procedures, which has established a set of firm barriers to active citizenship, leading to the emergence of different forms of collective action in the healthcare domain (Matos, 2011). Given the scarcity of institutionalised forms of participation, both protests and patient associations are considered the major outlets for the public demands of citizens and specific groups or collectives in Portuguese society. These collective mobilisations tend, in particular, to emerge in situations where people feel more directly affected by problems associated with access and the quality of public services.

Strong protest actions associated with the health system have taken place in the last decade, specifically against the closure of health centre emergency units and maternity wards, which intensified in 2006-2007. In Portugal, patient associations are emerging as new collective actors with increasing visibility (Nunes et al., 2007). The Portuguese patient associations have a relatively recent history, having emerged particularly in the post-25 April 1974 period (i.e. since the revolution that marked country's transition to democracy), and the majority were founded in the last decade. Patient associations have opened up new arenas for debate and proposed alternatives for health governance, as well as healthcare practices.

More recently, some innovative and institutionalised participatory practices have also been implemented to increase citizen engagement and trust in the Portuguese healthcare system: a) the creation, in each of the five regional administrations, of a monitoring observatory to provide a greater level of satisfaction and to guarantee the effective involvement of citizens; b) the implementation of a direct electronic communication system to facilitate the exchange of information between users and their family doctors; c) the establishment of some consultative mechanisms for the health system. The most important of these is the Community Councils (Conselhos de Comunidade - CC), established within Primary Health Centre Groups and implemented through Decree Law No. 28/2008. The Councils were created with the aim of reducing inequalities in healthcare, preventing the marginalisation of primary healthcare, centrally involving the community in shaping primary care services and encouraging users to become involved in decisions regarding their healthcare. The Portuguese CCs are made up of representatives of municipal assemblies, social security district centres, schools, third sector welfare institutions, user associations, trade unions, employers, volunteers, commissions for the protection of children and young people, and referring hospitals. By 2011 almost 80\% of the Health Centre Groups had created their 
respective $\mathrm{CC}$. The obstacles identified during the process of establishing the CCs include the following: i) the time taken to appoint representatives of different institutions; ii) the excessive influence of the municipal authorities; iii) the lack of user associations needed to form the CCs (OPSS, 2011). The most critical point, at least in this initial phase in the implementation of the CCs, is the limited presence of user associations in the Health Centre Group areas. Moreover, it is questionable whether the actual composition of the CCs is appropriate in terms of giving a voice to the users of primary healthcare. In other words, faced with the large presence of representatives of municipal councils and other institutions, user representation, consisting of just one member, may not be considered sufficient.

\subsection{Spain}

In Spain, citizen participation in National Health Service was introduced by the Ley General de Sanidad (General Health Law). The law created the Consejos de Salud (Health Councils) in the Health Districts of the Autonomous Communities, consisting of representatives of local associations (50\%), health professionals' trade unions (25\%), and Health District administrators (25\%). However, they resulted in a "not very active" mechanism (Segura, 2010: 60) which was "more symbolic than real" (Irigoyen, 2004: 78). The "imperfections" and "inefficiencies" resulting from the current channels for participation, which are based on purely consultative participation, have been stressed as major weaknesses (MartínGarcía et al., 2006). The Law on Cohesion and Quality, for example, established the Advisory Council for Participation in the NHS as a means of implementing public participation in the formulation of national health policy. This council is composed of representatives of the General Administration and the Autonomous Communities, businesses, organisations and trade unions but, paradoxically, excludes patient and user representatives (RuizGiménez, 2011), which implies a lack of participation throughout the Spanish NHS (Martín-García et al., 2006; Aguilar, 2006).

In recent years, some Autonomous Communities have introduced new participatory mechanisms within their regional healthcare systems. Aiming to boost citizen participation in health councils, the Autonomous Community of Castilla La Mancha developed a new participatory device based on the main principles of deliberative democracy. Within this new procedure three participatory mechanisms were established in 2007 in the Puertollano health district: a Forum (made up of patient association representatives as well as individual users), a Participatory and Administrative Council (consisting of the Health Forum coordinator, executives and professionals from the health district), and a Virtual Forum. The strong points of this experience are the citizens' interest and enthusiasm in participating, the growing number of associations engaged in the participatory project, and the number of proposals sent to the Health Forum (Bleda et al., 2008). The main challenges it faces are the inadequate training provided for participants, both citizens and professionals and administrators, the lack of financial resources and the disproportionate involvement of political decision-makers. Despite the positive assessment of the early years, the political change in regional government in 2011 led to a growing paralysis of the Puertollano experience and its possible extension to other areas of the Community of Castilla-La Mancha.

In 2008-09, a reform of the regional healthcare system also took place in the Community of Aragón, based on citizen participation and improving health services. Citizens and community representatives, together with professionals and administrators, were involved in several activities which included identifying needs and health problems and taking part in workshops, assemblies and working groups, involving around 700 participants (Gobierno de Aragón, 2009). The process culminated in the elaboration of a proposed participatory model, which was expected to be tested in 17 health zones and duly evaluated with a view to extending it to the whole autonomous community, starting in 2011. As in the case of the Puertollano experience, the change of government and the consequent change in policy orientation put an end to this plan.

Another relevant participatory activity was carried out in 2004-2008, in an economically and socially disadvantaged area of Badajoz city, which is part of the Extremadura Autonomous Community. As a first step towards the participatory process, a Community Health Committee was founded as a permanent institution, composed of associated citizens' representatives, administrators and health professionals, but also open to individual citizens. Subsequently, a community assessment was carried out, providing a shared and comprehensive vision of community health needs and priorities. On the basis of these results, the Committee produced a health plan and a set of community interventions. However, this experience revealed some difficulties due to the lack of training for the healthcare professional teams and limited institutional support (Maynar et al., 2010).

In the Community of Catalonia, Decree 38 of 2006 established the Governs Territorials de Salut (GTS - Health Territorial Governments). These were consortia, designed to achieve a greater level of coordination and integration within the health system between local governments and the government of the Autonomous Community. Each territorial government includes a Health Council and a public participation mechanism with consulting and monitoring duties. The councils include representatives of trade unions, business organisations, neighbourhood associations and patient and user organisations. In 2009, 34 (out of the expected 37) health councils were operating and 52 were expected to be created (Generalitat de Catalunya, 2010). However, this is a relatively new experiment and the results cannot be evaluated properly yet.

At national level, another boost for participation emerged with the new model for Primary Health Care, Family and Community Medicine. Since 1990, this programme has been developing community-oriented work through the identification of health needs and the evaluation of results. In 2006, a national survey carried out in primary health centres revealed that only 6\% of PHCs had developed some participatory activities (Martín-García et al., 2006).

\section{Concluding remarks}

The evolution of the national health services in the three countries under review in this article shares a common history, as well as similar models for the organisation and provision of services. These developments began in the late 1970s (Italy and Portugal) and early 1980s (Spain) with the creation of the national health systems which, over time, proved their ability to legally establish user rights, although they did not always ensure the effective exercise of such rights. Since their establishment, common problems have affected the health systems of all three countries, mostly related to the quality of services, their lack of efficiency and persistent issues concerning inequality. In recent years, in order to overcome such weaknesses, Italy, Portugal and Spain have carried out reforms to their health systems, in which participatory mechanisms were considered crucial. Since then, several participatory mechanisms have been introduced into the health system, involving different formats, different paces and different impacts on health policies.

As a consequence, there has been a clear increase in the discourse of proactive participation in the healthcare domain, but 
very little contact with real practices, particularly with regard to civil society's expected empowerment in participatory activities and influence on health decisions. Most of the participatory activities implemented in the three countries have become the privilege of only a few groups in civil society and on a merely consultative basis, without any guarantee of their possible impact on health policies.

With regard to the participatory experiences identified within the three Southern European countries, some final considerations should be highlighted. The promotion of participation emerges, in this context, as a strategic democratic principle, although it has proved difficult to implement, probably because most of the experiments only took place on a local or regional level. Moreover, despite some experiences of participation which appeared promising in terms of their innovative aspects, the lack of any assessment of their quality, efficiency and sustainability should be condemned.

Finally, it is important to note that the current financial crisis affecting Southern European countries, particularly those under review here, has not spared the national health systems. As a consequence of the austerity measures which have been implemented, citizens' participatory mechanisms have heavily been affected by budget cuts. A sharp decline in government interest and investment in such practices is leading to the curtailment of participatory activities within healthcare systems. However, although the crisis is halting the expansion of the existing institutionalised forms of participation, it is also revitalizing some unconventional forms of participation, such as protests. Thus, protests and the social movements associated with health systems are increasing in this European region. These forms of collective action reflect the pressure from civil society for participation in decisionmaking processes and represent a serious warning to governments, since citizens are claiming that once regular participatory practices have been implemented, they will not allow this process to be reversed.

\section{References}

Abelson, J., Forest, P.G., Eyles, J., Smith, P., Martin, E., Gauvin, F.P., 2003. Deliberations about deliberative methods: issues in the design and evaluation of public participation processes. Soc. Sci. Med. 57 (2), 239-251.

Aguilar, M.J., 2006. Participación comunitaria en salud: balance crítico sobre los consejos de salud y otras experiencias participativas en Atención Primaria. Rev. Comunidad. 5, 66-81.

Altieri, L., 2009. Valutazione participazione. Metodologie per una ricerca interattiva e negoziale. Angeli Editore, Milan.

Ardigò, A., 1997. Società e salute. Lineamenti di sociologia sanitaria. Angeli, Milan. Augusto, G.F., 2012. Cuts in Portugal's NHS Could compromise care. Lancet 379, 400.

Barros, P.P., 2012. Health policy reform in tough times: the case of Portugal. Health Policy 106, 17-22.

Barros, P., Simões, J., 2007. Portugal: health system review. Health Syst. Transit. 9 (5), $1-140$.

Belvis, A.G., Ferrè, F., Specchia, M.L., Valerio, L., Fattore, G., Ricciardi, W., 2012. The financial crisis in Italy: implications for the health care sector. Health Policy 106, 10-16.

Bentes, M., Dias, C.M., Sakellarides, C., Bankauskaite, V., 2004. Health care systems in transition: Portugal. In: Cph. WHO Regional Office Eur. behalf Eur. Observatory on Health Syst. Policies.

Biocca, M. (Ed.), 2006. Cittadini competenti costruiscono azioni per la salute. Angeli, Milan.

Bleda, J.M., Goméz, Á.S., Carretero, C.F., 2008. Diseño de un modelo de participación ciudadana en salud en la Comunidad de Castilla-La Manche e implementación del mismo en el Área de Salud de Puertollano (2005-2008). Rev. Adm. Sanit. 6 (4), 699-714.

Bovemkamp, H.M., Trappenburg, M.J., Grit, K.J., 2009. Patient participation in collective healthcare decision making: the Dutch Model. Health Expect. 13, 73-83.

Cabiedes, L., Guillén, A.M., 2001. Adopting and adapting managed competition: health care reform in Southern Europe. Soc. Sci. \& Med. 52 (8), 1205-1217.

Cervia, S., 2011. Governare la salute. Una riflessione sul modello di network toscano. Riv. Trimest. Sci. dell'Amministrazione 4, 101-120.

Charles, C., DeMaio, S., 1993. Lay participation in health care decision: a conceptual framework. J. Health Politics, Policy Law 18, 881-904.
Cohen, J., 1997. Procedure and substance in deliberative democracy. In: Bohman, J. Rehg, W. (Eds.), Deliberative Democracy. MIT Press, Cambridge MA, pp. 407-437.

Cooper, L., Coote, A., Davies, A., Jackson, C., 1995. Voices off: Tackling the Democratic Deficit in Health. Institute for Public Policy Research (IPPR), London.

Corposanto, C., Passerini, A., 2002. La costruzione partecipata della carta dei servizi. Salute Soc. 2, 24-45.

Delli Carpini, M., Cook, F.L., Jacobs, L., 2004. Public deliberation, discursive participation, and citizen engagement: a review of the empirical literature. Annu. Rev. Political Sci. 7, 315-344.

Dirindin, N., Pagano, E. (Eds.), 2001. Governare il federalismo. Le sfide per la sanità. Il Pensiero Scientifico Editore, Roma.

Dryzek, J., 2009. Democratization as deliberative capacity Building. Comp. Polit Stud. 42 (11), 1379-1409.

Esping-Andersen, G., 1990. The Three Worlds of Welfare Capitalism. Polity Press, Cambridge.

Faria, P., 2011. Saúde pública e crise: uma reflexão. Rev. Port. Saúde Pública 29 (2), 97-99.

Fernandes, A.C., 2011. A crise e os desafios e o sistema de saúde. Rev. Port. Gestão Saúde 5, 4-5.

Ferrera, M., 1996. The 'Southern model' of welfare in social europe. J. Eur. Soc. Policy $6,17-37$.

Figueras, J., Mossialos, E., McKee, M., Sassi, F., 1994. Health care systems in southern europe: is there a Mediterranean Paradigm? Int. J. Health Sci. 5 (4), 135-146.

Frankish, C.J., Kwan, B., Ratner, P.A., Warf Higgins, J., Larsen, C., 2002. Challenges of citizen participation in regional health authorities. Soc. Sci. \& Med. 54, $1471-1480$

Garcia Rada, A., 2012. New legislation transforms Spain's health system from universal access to one based on employment. Br. Med. J. 344, e3196.

Generalitat de Catalunya, 2010. Departamento de Salud. El sist. atención la salud Cataluña: evolución orientaciones estratégicas la perspect. del Servicio Catalán la Salud. Barc (Generalitat de Catalunya).

Giarelli, G., 2006. Il paradigma mediterraneo? Riforme sanitarie e società nell'Europa meridionale. Salute Soc. IV (Suppl),

Giarelli, G., Nigris, D., Spina, E., 2012. La sfida dell'auto-mutuo aiuto. Associazionismo di cittadinanza e sistema socio-sanitario. Carocci, Rome.

Gobierno de Aragón, 2009. Borrador de propuesta de modelo de participación en salud. Gobierno de Aragón, Saragoza.

Graça, L., Loureiro, I., 2012. A(s) crise(s) e a(s) resposta(s) da saúde pública. Rev. Port. Saúde Pública 30 (2), 103-104.

Guillén, A., 2002. The politics of universalization: establishing NHS in Southern Europe. West Eur. Polit. 25 (4), 49-68.

Gutmann, A., Thompson, D., 2004. Why Deliberative Democracy? Princeton University Press, New Jersey.

Habermas, J., 1996. Between Facts and Norms. Polity, Cambridge.

Harrison, S., Mort, M., 1998. Which champions, which people? Public and user involvement in health care as a technology of legitimation. Soc. Policy \& Adm. $32,60-70$.

Health Consumer Powerhouse, 2009. The Empowerment of the European Patients 2009. Options and Implications. Health Consumer Powerhouse, Brussels, pp. $1-56$.

Irigoyen, J., 2004. Perspectivas de la participación en salud después de la reforma gerencialista. Rev. Comunidad 7, 73-79.

Jovell, A., 2008. La visión de los pacientes. Rev. Adm. Sanit. 6 (1), 33-39.

Karamessini, M., 2007. The Southern European Social Model: Changes and Continuities in Recent Decades. International Institute for Labour Studies, Geneva: International Labour Organization (ILO).

Karanikolos, M., Mladovsky, P., Cylus, J., Thomson, S., Basu, S., Stucler, D. Mackenback, J., McKee, M., 2013. Financial crisis, austerity, and health in Europe. Lancet 381 (9874), 1323-1331.

Lehoux, P., Daudelin, G., Demers-Payette, O., Boivin, A., 2009. Fostering deliberations about health innovation: what do we want to know from publics? Soc. Sci. Med. 68, 2002-2209.

Lo Scalzo, A., Donatini, A., Orzella, L., Cicchetti, A., Profili, S., Marasso, A., 2009. Italy: health system review. Health Syst. Transition 11 (1), 1-216.

Maino, F., 2009. Il sistema sanitario italiano tra contenimento della spesa, malasanità e politicizzazione. In: Baldini, G., Cento Bull, A. (Eds.), Politica in Italia: i fatti dell'anno e le interpretazioni, pp. 241-260. Bologna: Il Mulino.

Martin, G., 2008. Ordinary People only: knowledge, representativeness, and the publics of public participation in healthcare. Sociol. Health Illn. 30, 35-54.

Martín-García, M., Ponte Mittelbrun, C., Sánchez Bayle, M., 2006. Participación social y orientación comunitaria en los servicios de salud. Gac. Sanit. 20 (supl 1), $192-202$.

Matos, A.R., 2011. A importância da participação cidadã nas políticas de saúde: o caso da reestruturação dos serviços de saúde materno-infantil em Portugal Saúde Soc. 20 (3), 604-616.

Maynar, I., Nieto, R., Montero de Espinosa, P., Madueño, M.A., Fernández, MãD. Maynar, M.A., 2010. Proyecto Progreso: un sistema sanitario participado para el desarrollo integral del modelo de Atención Primaria de Salud. Rev. Comunidad $12,15-26$.

Neveu, C., 2011. Démocratie participative et mouvements sociaux: entre domestication et ensauvagement. Participations 1, 186-209.

Newman, J. (Ed.), 2005. Remaking Governance. Peoples, Politics and the Public Sphere. The Policy Press, Bristol. 
Nicoli, M.A., Capizzi, S., Perino, A., Cipolla, C., 2006. Sulle tracce di una metodologia sociale appresa collettivamente. In: Biocca, M. (Ed.), Cittadini competenti costruiscono azioni per la salute, pp. 118-151. Milan: Angeli.

Nunes, J.A., Matias, M., Filipe, Â.M., 2007. As organizações de pacientes como actores emergentes no espaço da saúde: O caso de Portugal. RECIIS - Rev. Eletrônica Comunicação, Informação Inovação em Saúde 1, 107-110.

OPSS, 2011. Observatório Português dos Sistemas de Saúde. In: Da depressão da crise para a governação perpsectiva da saúde. Coimbra: Mar de palavra.

Palazzi, M., Zani, B. Altieri, L., 2002. Attori o spettatori? Ascolto e partecipazione de cittadini nei piani per la salute dell'Emilia-Romagna. Salute Soc. 1 (1), 127-146.

Pateman, C., 2012. Participatory democracy Revisited. Perspectives Politics 10 (1), 7-19.

Portugal Ministério da Saúde, 2004. Plano Nacional de Saúde 2004-2010. DirecçãoGeral da Saúde, Lisbon.

Rhodes, M., 1998. Southern European welfare: identiy, problems and prospects South Eur. Soc. Politics 1 (3), $1-22$

Rifkin, S., 2009. Lessons from the community participation in health programmes. A review of the post Alma-Ata experience. Int. Health 1, 31-36.

Roberts, N.C., 2008. The Age of Direct Citizen Participation. Armonk/New York: M.E Sharpe.

Rowe, G., Frewer, L.J., 2004. Evaluating public-participation exercises: a Research agenda. Sci. Technol. Hum. Values 29 (4), 512-556.

Ruiz-Giménez, J.L., 2011. Luces y sombras en la participación comunitaria en salud. In: Palomo, L. (Ed.), Treinta años del Sistema Sanitario Español. FADSP, Madrid, pp. 205-222.
Sánchez Bayle, M., 2003. Los retos del sistema de salud. Rev. Adm. Sanit. 1 (3), $471-486$.

Santos, B.S., 1998. Reinventar a Democracia. Gradiva, Lisbon.

Santos, B.S., 2002. Democratizar a democracia: os caminhos da democracia participativa. Civilização Brasileira, Rio de Janeiro.

Scuthfield, F.D., Hall, L., Ireson, C.L., 2006. The public and public health organizations: issues for community engagement in public health. Heath Policy 77, $76-85$.

Segura, A., 2010. La participación ciudadana, la sanidad y la salud. Gest. Clínica Sanit. 12 (2), 55-62.

Serapioni, M., Duxbury, N., 2012. Citizens' participation in the Italian healthcare system: the experience of the Mixed Advisory Committees. Health Expect http://dx.doi.org/10.1111/j.1369-7625.2012.00775.x.

Serapioni, M., Matos, A.R., 2013. Participação em saúde: entre limites e desafios, rumos e estratégias. Rev. Port. Saúde Pública 31 (1), 11-22.

Tritter, J.Q., McCallum, A., 2006. The snakes and ladders of user involvement: moving beyond Arnstein. Health Policy 76, 156-158.

Viegas, J.M.L., 2004. Implicações democráticas das associações voluntárias. O caso português numa perspectiva comparativa europeia. Sociol. Probl. Prat. 46, 33-50.

WHO Regional Office for Europe, 2002. Community Participation in Local Health \& Sustainable Development. Approaches and Techniques. World Regional Office for Europe, Copenhagen.

Zakus, D., Lysack, C., 1998. Revisiting community participation. Health, Policy Plan. $13,1-12$. 